\title{
Examination of Faecal Caliform Presence in Groundwater in Ghana (A Case Study in Ketu South Municipality)
}

\author{
${ }^{* 1}$ SETH Y. AHIABOR. ${ }^{2}$ AUSTIN D. AMOAKO \\ 1. University of Health \& Allied Sciences - School of Public Health - Ghana. \\ 2. $\quad$ PMB 38, Ho - Volta Region - Ghana.: E-Mail: sahiabor@yahoo.com, Tel: +233244 154406 \\ 3. Kwame Nkrumah University of Science \& Technology - Ghana. \\ KNUST-AISWAM, PMB 219, Madina-Accra.E-Mail: aaustindickson@yahoo.com, Tel: +233244751673
}

\begin{abstract}
Samples were taken from wide-dam, open wells and compared with piped city water. Well water from both districts showed widespread contamination with faecal bacteria. This study revealed high Faecal and Total coliforms in all the samples with varying numbers. The high coliforms content of the eight hand-dug wells poses a health risk and renders the water unsuitable for human consumption. The presence of pathogenic organisms in the water could be attributed to pit latrine in the vicinity that extent their influence on these water qualities, since they are sited close to them. C JASEM
\end{abstract}

http://dx.doi.org/10.4314/jasem.v20i1.5

\section{Introduction}

Water-borne diseases are diseases that are transmitted through the direct ingestion of water contaminated with pathogens. In this case, the organisms normally reside and can survive in polluted water. Most of the diseases caused here are diarrhoeal diseases and may involve bacteria, viruses or protozoa or a combination of all. Transmission of water-borne diseases can be prevented by assuring access to a sufficient quantity of disinfected water, proper disposal of human waste, and improved hygiene. The pollution of groundwater, which remains the main source of supply in drinking water in the study area, is steadily increasing. Pathogenic bacteria exist at soil surfaces and this could be introduced into the water by anthropogenic activity. Rainfall is a major factor affecting vertical and horizontal movement of bacteria in soil. Surface runoff caries bacteria significant distances downstream causing serious threats to ground and surface waters.

In Albanian capital, where drinking water having microbiological pollution posed a major problem, Angjeli et al. (2000) investigated a link between contamination of drinking water and domestic sewage.

According to Gelinas et al. (1996), bacteriology and physiological quality of well water from 2 districts of Conakry was determined during the 1994 dry season. (Ahiabor and Amoako 2015) reported that conservation of high-quality water resources for domestic supply becomes increasingly important as a result of drastic rise in population growth. They again argued that the above assertion can undoubtedly provide a strong argument for the necessity to protect groundwater against contamination. It should be noted, however, that the protection of particular groundwater resources is also dependent on whether it is considered as a key source of domestic water in the long-term.

Water supplies and sanitation management is a basic dimension of sustainability. However, water resources at large are poorly protected and managed, especially in the under developed nations lending credence to the fact that water supply issues cannot be sustainably resolved without also providing proper sanitation (Ahiabor and Amoako 2015).

\section{MATERIALS AND METHODS}

In this research, water samples from the hand-dug wells were collected for six months; three in the dry season and three in the wet season. At each sampling site, water samples were collected from wells, which served as the main source of drinking water for the people.

Analyses were carried out at two different laboratories. Faecal Caliform analyses were carried out in Ecological Laboratory which is located at the Department of Geography and Resource Development, University of Ghana. 
RESULTS AND DISCUSSION

Table 1: Total Coliform (count/100ml) at the sampling sites

\begin{tabular}{|c|c|c|c|c|c|c|c|c|c|c|}
\hline \multirow[t]{2}{*}{ SITE } & \multicolumn{3}{|c|}{ DRY SEASON } & \multicolumn{3}{|c|}{ WET SEASON } & \multirow[t]{2}{*}{ MIN } & \multirow[t]{2}{*}{ MAX } & \multirow{2}{*}{$\begin{array}{l}\text { MEAN DRY } \\
\text { SEASON }\end{array}$} & \multirow{2}{*}{$\begin{array}{l}\text { MEAN WET } \\
\text { SEASON }\end{array}$} \\
\hline & NOV & $\overline{\text { DEC }}$ & JAN & $\overline{\text { APR }}$ & MAY & JUN & & & & \\
\hline XE & 124 & 100 & 460 & 100 & 124 & 101 & 100 & 460 & 228 & 108.3 \\
\hline DK1 & 42 & 40 & 80 & 40 & 60 & 76 & 40 & 80 & 54 & 58.67 \\
\hline DK2 & 1456 & 1408 & 2560 & 440 & 424 & 442 & 424 & 2560 & 1808 & 435.3 \\
\hline AD1 & 348 & 312 & 220 & 220 & 342 & 265 & 220 & 348 & 293.3 & 275.7 \\
\hline AD2 & 1328 & 1164 & 1240 & 340 & 1221 & 1542 & 340 & 1542 & 1244 & 1034 \\
\hline GK & 100 & 100 & 80 & 0 & 70 & 84 & 0 & 100 & 93.33 & 51.33 \\
\hline AG & 1272 & 972 & 1680 & 420 & 982 & 788 & 420 & 1680 & 1308 & 730 \\
\hline \multirow[t]{2}{*}{$\mathbf{A S}$} & 1216 & 1378 & 1280 & 1200 & 1214 & 1543 & 1200 & 1543 & 1291 & 1319 \\
\hline & & & & WHC & & & & & & \\
\hline GWC & & & & & & & & & & \\
\hline
\end{tabular}

GWC (1997) Maximum Limits Recommended for drinking and domestic uses of water WHO (1993) guide for drinking water Standard not available

Table 2: Faecal Coliform (count/100ml) at the sampling sites

\begin{tabular}{|c|c|c|c|c|c|c|c|c|c|c|}
\hline \multirow[t]{2}{*}{$\overline{\text { SITE }}$} & \multicolumn{2}{|c|}{ DRY SEASON } & \multicolumn{4}{|c|}{ WET SEASON } & \multirow[t]{2}{*}{ MIN } & \multirow[t]{2}{*}{ MAX } & \multirow{2}{*}{$\begin{array}{c}\text { MEAN DRY } \\
\text { SEASON }\end{array}$} & \multirow{2}{*}{$\begin{array}{l}\text { MEAN WET } \\
\text { SEASON }\end{array}$} \\
\hline & NOV & $\overline{\text { DEC }}$ & JAN & APR & MAY & JUN & & & & \\
\hline $\mathbf{X E}$ & 36 & 0 & 300 & 80 & 90 & 60 & 0 & 300 & 112 & 76.67 \\
\hline DK1 & 0 & 0 & 20 & 20 & 24 & 56 & 0 & 56 & 6.667 & 33.33 \\
\hline DK2 & 476 & 428 & 500 & 100 & 102 & 124 & 100 & 500 & 468 & 108.7 \\
\hline AD1 & 172 & 100 & 80 & 80 & 162 & 156 & 80 & 172 & 117.3 & 132.7 \\
\hline AD2 & 572 & 404 & 280 & 120 & 342 & 346 & 120 & 572 & 418.7 & 269.3 \\
\hline GK & 26 & 30 & 0 & 0 & 5 & 10 & 0 & 30 & 18.67 & 5 \\
\hline $\mathbf{A G}$ & 456 & 228 & 600 & 200 & 212 & 342 & 200 & 600 & 428 & 251.3 \\
\hline \multirow[t]{3}{*}{$\mathbf{A S}$} & 408 & 500 & 200 & 380 & 412 & 322 & 200 & 500 & 369.3 & 371.3 \\
\hline & & & & WHO & & & & & \multicolumn{2}{|c|}{ 0 } \\
\hline & & & & GWC & & & & & \multicolumn{2}{|c|}{ 0 } \\
\hline
\end{tabular}

GWC (1997) Maximum Limits Recommended for drinking and domestic uses of water WHO (1993) guide for drinking water Standard not available

For water to be considered risk free to human, the total bacteria and E. coli in water sample should be zero and total heterotrophic bacteria (THB) count should not exceed 500cfu/ml (WHO, 2004). This study revealed high Faecal and Total coliforms in all the samples with varying numbers. The high coliforms content of the eight hand-dug wells poses a health risk and renders the water unsuitable for human consumption. The presence of pathogenic organisms in the water could be attributed to pit latrine in the vicinity that extent their influence on these water qualities, since they are sited close to them. Ground water flow is either lateral or vertical. During lateral flow, filtration does not occur and could carry faecal pollution for much longer distance (Cairncross, 1987).

The hand-dug wells water in the districts were characterized by high total and faecal coliforms. The abundance of the TC, FC underwent high spatial and temporal fluctuations. The box plot (fig. 16) for the eight sampling sites showed that total coliform recorded the maximum number throughout the period.

In a similar work done by Umar (2008), in Asamankese in the Eastern Region of Ghana he found high microbial indicators in the wells. The study related the level of contamination of water to the lateral distance between pit latrine and wells. This corroborates the high counts of microbial loads obtained in hand-dug wells in this study. Results confirm the important role of runoff in bacterial transport on soil surfaces. They show E. coli survive in semiarid areas for a long time and increases potential of contamination (Ashour and Hung, 2000).

The sanitation survey revealed that most of the wells did not have cover slabs. Well water was usually drawn using various receptacles (plastic or aluminum buckets) with varying degrees of hygiene. (Plate 1)

Conclusion and Recommendation: The construction and depth of the hand-dug wells could further explain contamination levels. The depth of the eight hand-dug wells studied ranged from $2.5 \mathrm{~m}$ to $20.5 \mathrm{~m}$. The interior lining of the wells were defective as they were fissured and five out of eight were without concrete lining. Ideally, wells should be constructed with concrete ring pipes but due to financial constraints only the upper part of about $2 \mathrm{~m}$ were cemented thus making it permeable to seepage. It could be discussed that all the studied hand-dug wells were sited within a $15 \mathrm{~m}$ or less radius from the pit latrine. The current situation predisposed the well water to bacterial contamination. 


\section{REFERENCE}

Angjeli, V.,Reme, B., Leno, L., Bukli, R., Bshati, G. (2002) sanitary survey of the drinking water supply of Kombinati suburb-Tirana, Albania. Schrifienr Ver Wasser Boden Lufthyg, 105, 187190.

Ahiabor and Amoako (2015). Groundwater Management and Storage Interventions in Rural Communities in Ghana. The International Journal of Science and Technolodge.

Amoako and Doe (2015). Effectiveness of Handwashing among Basic School Children in Sunyani Township. International Journal of Scientific and Engineering Research. 5,

Ashour, A.J., Hung, L. (2000) Transport of bacteria on bacteria on sloping soil surfaces by runoff. Environmental Toxicology, 15, 2, 149-153.
Caircross, S.,Cliff, J.L.(1987). Water use and health in Mireda, Mozambique. Trans.Royal society. Tropical Medical Hygeine. 81:51-54

Gelinas Y, Randall H, Robidoux L, Schmit J-P, (1996) Well water survey in two Districts of Conakry (republic of Guinea) and comparison with the piped city water Water Resources 30(9): 2017-2026.

WHO (2004). Guidelines for drinking-water quality, Volume 1: Recommendations. WHO, Geneva (3rd edition).

WHO (1993). Guidelines for drinking-water quality, Volume 1: Recommendations. WHO, Geneva (2nd edition). 